\title{
COMPARISON OF WILD BEE COMMUNITIES OF THREE SEMI-NATURAL MEADOW HABITATS AT HARGHITA-COVASNA REGION, TRANSYLVANIA, ROMANIA
}

\author{
Imre Demeter ${ }^{1}$, Adalbert Balog ${ }^{2}$, Zsolt Józan ${ }^{3}$ and Miklós Sárospataki ${ }^{1 *}$ \\ ${ }^{1}$ Department of Zoology and Ecology, Hungarian University of Agriculture and Life Sciences \\ H-2100 Gödöllö, Páter K. u. 1, Hungary \\ E-mail: demeter_imre@yahoo.com; https://orcid.org/0000-0002-5851-6179 \\ E-mail: Sarospataki.Miklos@uni-mate.hu; https://orcid.org/0000-0002-3306-1470 \\ ${ }^{*}$ Corresponding author \\ ${ }^{2}$ Department of Horticulture, Faculty of Technical and Human Science \\ Sapientia Hungarian University of Transylvania, Sighisoara Str. 1C. Tirgu-Mures, Romania \\ E-mail: adalbert.balog@ms.sapientia.ro; https://orcid.org/0000-0001-7772-7783 \\ ${ }^{3}$ H-7453 Mernye, Rákóczi út 5, Hungary; E-mail: jozan.zsolt@citromail.hu
}

In the temperate climate wild bees are the most important pollinator organisms. Pollination is essential for the communities of semi-natural habitats since this ecosystem service directly affects plant reproduction. The diversity of wild bees living in such areas is remarkably high, but they are susceptible to various anthropogenic influences.

In our study, the composition and structure of wild bee communities were examined in Romania (Transylvania) at three semi-natural areas near Filia, Merești and Vârghiș. The surveyed areas were used as extensive meadows under relatively low but slightly different anthropogenic influence levels. We collected bees in these areas at several places (9 sampling points/area) by individual netting four times during the season. In the studied areas, 129 bee species were found, which makes up about $18 \%$ of the approximately 726 wild bee species registered in Romania. In addition to the high number of species, we also observed high diversity values. Our results showed that, even at our sampling site closest to the human settlements, the extensive use of the surveyed areas as meadows allows the development of diverse, species-rich bee communities.

Keywords: bumble bee, wild bee communities, diversity, pollination, solitary bee, Transylvania, meadow.

\section{INTRODUCTION}

One of the main reasons for the biodiversity decline is the intensive agricultural land use, which reduces natural habitats (Newbold et al. 2015). The habitat fragmentation and land use change result is a homogeneous landscape structure (Tilman et al. 2001). Intensive agriculture results in a loss of biodiversity (DE HeER et al. 2005), which also leads to a decline in ecosystem services, including pollination, in many regions of the world (KREMEN et al. 2002, Kremen et al. 2007, PotTs et al. 2016). 
The role of bees in pollination is particularly significant as they are responsible for pollinating many nutrient-rich plants important for human nutrition (Ellis et al. 2015). More than 70\% of the essential food crops depend on bee pollination (KLEIN et al. 2007), a service worth $€ 153$ billion worldwide (GALla et al. 2009). The presence of wild bees in crop production is relevant even when the presence of honey bees is strong, because wild bee communities often prove to be more efficient pollinators than honey bees and inter-species interactions can increase pollination efficiency (BRITTAIN et al. 2013, Woodсоск et al. 2013). Diverse bee communities provide a high and stable supply of pollination services (Hoenn et al. 2008, Eeraerts et al. 2020, MacInnis et al. 2020), but recently the intensification of agriculture has greatly reduced the diversity and abundance of bee communities (Goulson 2003, Biesmeijer et al. 2006, Goulson et al. 2008, Роттs et al. 2010). In more recent decades new farming systems and techniques have been developed through organic farming and agri-environmental schemes (AES), to mitigate the impacts mentioned above (SAMu et al. 2010, Andersson et al. 2012, BAtáry et al. 2015).

Pollination by wild bees is vital not only in agricultural areas but also in semi-natural habitats as it has a direct effect on the reproduction of plants, which form the basis of all (semi)natural communities. The main drivers of wild bee decline are related to historical landscape change, loss of natural and semi-natural areas, loss of nesting and feeding grounds, and loss of the most important flower sources (Goulson et al. 2005, Ротts et al. 2005, Senapathi et al. 2015, BAude et al. 2016, SÁrospataki et al. 2016). The breaking up and the utilisation of semi-natural areas for intensive cultivation lead to habitat fragmentation, which can adversely affect the size and interconnectivity of remaining habitat patches (Нооке et al. 2012). It may reduce gene flow between pollinator populations in the short term and may impact population persistence in the long term (DARviLl et al. 2010).

In Europe, the natural, especially grassland habitats without any anthropogenic effects are almost absent (Evans 2006). However, high nature value $(\mathrm{HNV})$ grasslands are present in Europe, and it is essential to have more information on the condition of these habitats (VeEN et al. 2009). The main reasons for the existence of the diverse semi-natural grasslands are local, regional (Myklestad \& Satersdal 2003), historical (Marini et al. 2009), traditional, long-term, small-scale and non-intensive land use (Poschlod et al. 2005, BABAI \& Molnár 2014, Dorresteijn et al. 2015). These systems in Europe have developed and sustained landscapes having a high natural, cultural, and aesthetic value (DAhlström et al. 2013). In the Romanian section of the Carpathians, there are large semi-natural, HNV pastures and hay meadows (HubAND et al. 2010). However, the intensity of land use (e.g., the number of mowing per year and manuring) of these habitats is reciprocally proportional with the proximity of the closest human settlements (Babai et al. 2015, Babai \& Molnár 2016). 
In this study, the community structure of wild bees in three semi-natural grassland areas in Romania (Transylvania) were examined. There was no information on the species composition and richness, and diversity of the pollinator communities of this area. The aim of our study was to (1) assess the diversity and species distribution of the wild bee communities living in the studied semi-natural, HNV areas, (2) collect new data on the rare and faunistically interesting species, (3) compare the bee communities of the three areas to understand the effects of various human presences.

\section{MATERIAL AND METHODS}

Our study was carried out in 2018 in Transylvania, in Harghita and Covasna counties, in three semi-natural, HNV areas where extensive farming takes place. In all three research areas, the average altitude is $530-630 \mathrm{~m}$. The studied areas are located relatively far from the closest villages, have preserved quite well the complex natural habitat consisting of grassland-woodland-scrub mosaics. The grasslands are mainly used as meadows. Mowing on mosaic grassland patches occurs at different times, thus providing a continuous food resource for pollinators. The studied meadows and grassland patches are part of valleys in all three cases. Although all three valleys are semi-natural, HNV meadows, there were little but noticeable differences in anthropogenic impacts between the sites.

One characteristic of traditional farming in this region is more intensive agriculture on lands closer to the villages. The majority of traditional treatments (indeed) increase landscape diversity, though not in all cases. Treatments that can have a negative impact on diversity are the extensive use of fertilisers and mowing more than twice a year. These treatments are carried out mostly on lands close to villages. Nevertheless, thanks to these practices, a larger amount of hay can be harvested from these neighbouring areas, which will suffice to feed the animals. Therefore, on remote areas one mowing a year is sufficient, and this allows more plants to produce seeds and thus increase the diversity of remote meadows (DAHLSTRÖм et al. 2013, BABAi et al. 2015, Kun et al. 2019).

Further reasons of the higher anthropogenic effect on the closer areas may be poor infrastructure (lands closer to the villages are easier to reach); protection of the areas (lands closer to villages can be protected easier against the damages caused by wildlife); traditional farming (currently this is less common, but up until recent years farmers were still using horse-drawn carts for harvesting).

The Filia $(\mathrm{F})$ area $\left(46.1731241^{\circ} \mathrm{N}, 25.6236372^{\circ} \mathrm{E}\right)$ is the closest to human settlements (the average geographic distance of this sampling site from the closest human settlements is about $2000 \mathrm{~m}$ ), with meadows, forest patches and few arable lands. The other two areas are relatively far from human settlements, and therefore the lands are used less intensively. Vârghiș Gorge (Cheile Vârghişului, V) area $\left(46.2034539^{\circ} \mathrm{N}, 25.5344264^{\circ} \mathrm{E}\right)$ is a nature reserve, located furthest from human settlements (the average geographic distance of this sampling site from the settlement is about $7500 \mathrm{~m}$ ), characterised by meadows and forest patches. The Merești $(\mathrm{M})$ area $\left(46.2394164^{\circ} \mathrm{N}, 25.5322366^{\circ} \mathrm{E}\right)$ is located at a medium distance from human settlements (the average geographic distance of this sampling site from the settlement is about $5000 \mathrm{~m}$ ), characterised by meadows, pastures and forest patches. The distances between the sampling areas were as follows: F-M 10000 m; F-V 7000 m; M-V 3700 m.

In all three valleys sampling was performed four times in 2018 (once in May, twice in June, once in July). The sampling area was a circle with a radius of $1200 \mathrm{~m}$ that contained 9 
sub-sampling sites. We randomly chose the 9 sub-sampling sites by picking the flower-rich meadows. Two people performed collection rounds for 20 minutes separately at each site while each of them walked along a $200 \mathrm{~m}$ transect. The distance between the two transects was approximately $50 \mathrm{~m}$, and there was no overlap between the transects. All observed wild bee individuals were captured using a butterfly net and preserved in $70 \%$ ethanol. Individuals were identified at species level by a taxonomic expert. The bees sampled at the same time by the two collectors were pooled.

The sampled specimens were divided into two groups, bumble bees and other wild bees (later referred to as solitary bees), as these may show significant differences partly in social behaviour and partly in home-range size (GATHMAnn et al. 2002, Michener 2000). Diversity indices (Shannon, Simpson) and diversity profiles (HiLl 1973) were calculated for both groups separately and the entire wild bee community. The endangered status of the species was determined based on the European Red List (NiETo et al. 2014). To characterise the differences of wild bee communities between areas, we compared the species composition and dominance relationships as well. Dominant and subdominant species were those with a dominance of more than $1 \%$ and $0.5 \%$, respectively. To compare species composition of the bee communities, we calculated Jaccard similarity indices analysing the areas in pairs.

\section{RESULTS}

During the sampling period, a total of 1882 individuals of 129 wild bee species were observed in the three areas. The complete list of species and the total number of individuals per area is provided in the Appendix. The collected material included 12 bumble bee species (1049 individuals) and 117 solitary wild bee species (833 individuals). According to the IUCN European Red List, one species can be classified as EN (Endangered), 11 species as NT (Near Threatened), and 24 species as DD (Data Deficient); the other species belong to the LC (Least Concern) category (see Appendix).

Table 1. Community parameters of the bee assemblages at the different sampling sites.

\begin{tabular}{lcccc}
\hline Site & Filia & Merești & Vârghiș & Total \\
\hline No. of individuals & 454 & 638 & 790 & 1882 \\
No. of species & 79 & 73 & 82 & 129 \\
No. of unique species at the given site & 22 & 13 & 25 & \\
No. of unique species with more than 1 specimen & 5 & 4 & 5 & \\
Shannon diversity & 3.37 & 2.74 & 2.72 & \\
Simpson diversity & 0.92 & 0.80 & 0.81 & \\
Shannon for bumble bees & 0.84 & 1.04 & 1.30 & \\
Simpson for bumble bees & 0.39 & 0.46 & 0.58 & \\
Shannon for solitary bees & 3.62 & 3.55 & 3.70 & \\
Simpson for solitary bees & 0.95 & 0.95 & 0.96 & \\
\hline
\end{tabular}



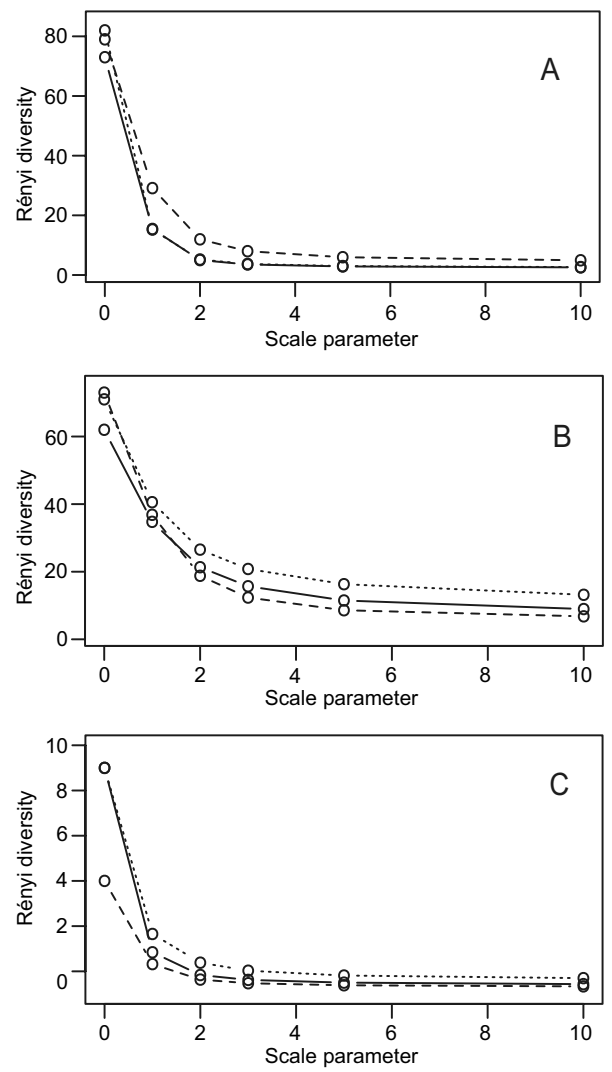

Fig. 1. Rényi diversity profiles of bee communities at the different sampling sites (Vârghiș: dotted line, Merești: solid line, Filia: dashed line). A: profiles for all species; B: profiles for solitary bee species; C: profiles for bumble bee species

Table 2. The number of common species (above the diagonal) and the Jaccard similarities (below the diagonal) of the given two sampling sites.

\begin{tabular}{lccc}
\hline & Filia & Merești & Vârghiș \\
\hline Filia & & 11 & 8 \\
Merești & 0.578 & & 12 \\
Vârghiș & 0.489 & 0.563 & \\
\hline
\end{tabular}

Species and individual numbers, and the number of unique species (species found only at the given area (F, M or V)) were highest in the area $\mathrm{V}$ (Table 1). Both the Shannon and Simpson indices showed very little difference between areas (Table 1). The diversity profiles of the areas also had a very similar course (Fig. 1). They intersect, so no significant difference in diversity could be assessed. The diversity profiles calculated for bumble bees is the only one where the curves did not intersect; nevertheless, they ran very close to each other. The number of unique species was highest at area $\mathrm{V}$, followed by $\mathrm{F}$ and then the $\mathrm{M}$ (Table 1). The number of common species at areas $\mathrm{M}-\mathrm{F}$ and $\mathrm{M}-\mathrm{V}$ was almost the same, while significantly fewer common species were found at the areas $\mathrm{F}-\mathrm{V}$ (Table 2). The values of the Jaccard similarity indices also showed the smallest similarity between the areas $\mathrm{F}-\mathrm{V}$, while area $\mathrm{M}$ was almost equally similar to both areas $\mathrm{V}$ and $\mathrm{F}$ (Table 2).

\section{DISCUSSION}

Our study has yielded important and exciting faunistic results. In recent faunistic works on Romanian bumble bees (BAN-CALEFARIU \& SÁRospataki 2007, Tomozi \& Toma 2011) faunistic data from this region (border of Harghita and Covasna counties) are lacking. Information on species on the European Red List is particularly important as new data in both endangered and data- 
deficient species may be necessary from a conservation perspective (NIETO et al. 2014). Out of the 11 species classified in the NT category, 5 were found as a single specimen only, but the other 6 proved to be more common, and some species proved to be dominant (Andrena ovatula (Kribz, 1802), 65 individuals) or subdominant (Andrena hattorfiana (Fabricius, 1775), 14 individuals) in our study. Out of the $24 \mathrm{DD}$ species, 17 were found in more than one specimen, and one of these was a subdominant species (Andrena schencki Morawitz, 1866, 11 individuals) of the community.

From a conservation biology perspective, it is fundamental to study the bee communities in semi-natural habitats, as the bees are the most important pollinators and have a direct impact on plant reproduction and thus on natural habitats (Bawa 1990, Ashman et al. 2004). Matache and Ban (2006) and BAN and Tomozei (2006) synthetised the data of publications and museum materials of Megachilidae, Andrenidae, Anthophoridae and Apidae from Dobrogea region. The data set was collected from more than 50 sampling sites, and it spanned several decades. They found 58 Megachilidae, 20 Andrenidae, 14 Anthophoridae, and 7 Apidae species. An intensive faunistical survey in Maramureș (6 years, 41 sampling sites) reported 12 Megachilidae, 5 Anthophoridae and 17 Apidae species (BAN 2005). On the other hand, in very similar faunistical surveys in Hungary (Sárospataki \& FazeKas 1995, Havas et al. 2008, SÁrospataki et al. 2009), the number of collected bee species ranged 65-124. In our study, we collected 23 Megachilidae, 21 Andrenidae, 19 Anthophoridae and 12 Apidae species, and the total species number was 129 in a one-year field survey. Hence, we can argue that the species richness of our sampling areas was very high. About $18 \%$ of the approximately 726 wild bees and $30 \%$ of the 40 Bombus species registered in Romania (http1.) were collected in our study areas.

In comparison to the species occurring in the Maramureș (Romania) region (BAN 2005) and Southern Transylvania (Kovács-HostYánszKi et al. 2016), a significant difference could be observed regarding the proportion of the wild bee individuals belonging to the different families. In our study, the largest number of collected specimens belonged to the family Apidae (61.3\%), and Halictidae $(20.4 \%)$, while in the Maramureș region the proportion of individuals of the two dominant families was reverse (Halictidae: 65.7\%; Apidae: 19\%). Similar results were found in Southern Transylvania: Halictidae (62\%), Apidae (17.2\%).

In addition to the high number of species, we also found high diversity values. In the three sample areas, the diversity of the communities did not significantly differ from each other (Table 1, Fig. 1). The highest number of species was observed in the $\mathrm{V}$ area, although the differences between the areas were not significant (F: 79, M: 73, V: 82 species). The two topographically closest areas were $\mathrm{M}$ and $\mathrm{V}$, and the similarity in their species composition was relatively high. However, area M showed fairly high similarity in species 
composition to area $\mathrm{F}$, which is topographically more distant from it, while area $\mathrm{V}$ and $\mathrm{F}$, which are relatively close to each other, had the least similarity. Area $\mathrm{V}$ is a protected area (http2.) and presents the most natural habitats, while area $\mathrm{F}$ is the most anthropogenic and closest to the human settlements.

The responses of pollinators to human-induced habitat disturbances are predominantly negative (WINFREE et al. 2011); however, the direction and strength of pollinator response are variable (WINFreE et al. 2009, 2011, QuiNTERo et al. 2010, Doré et al. 2021). Furthermore, changes in pollinator richness and abundance may vary among disturbance types (Doré et al. 2021) and were significantly reduced by habitat change only in systems experiencing extreme habitat loss (WINFReE et al. 2009). Other community parameters (e.g. species composition, the relative abundance of specialist and generalist species) are often more sensitive to the anthropogenic effects (WINFreE et al. 2011, Quintero et al. 2010). Our study sites were semi-natural, HNV meadows, and there were little variances in anthropogenic effect between the sites derived only from the mowing intensity (see Materials and methods, DAHLström et al., 2013, ВАВAI et al. 2015, Kun et al. 2019). This little variance in the anthropogenic influence between the areas was probably not enough to cause significant species number and diversity differences based on our results. However, although not strongly, differences in anthropogenic effects can be detected based on the similarities/differences in species composition. After all, the two areas with the most different anthropogenic effects (V-F), showed the least similarity in species composition, even though they were closest to each other.

Our study suggests that the extensive use of the surveyed areas as meadows allows for developing diverse, species-rich bee communities, even at our sampling site closest to the human settlements. The monitoring of the bee communities of these and similar meadows could present useful data for the conservation of these high-value grasslands.

Acknowledgements - We thank Annamária Incze for help in field surveys. We are grateful to the Agenția Națională pentru Arii Naturale Protejate for the research permissions in the protected areas. During the work, I. D. had a PhD "Collegium Talentum" research grant from the Sapientia Hungariae Foundation. We would like to acknowledge the valuable comments and suggestions of the reviewers.

\section{REFERENCES}

Andersson, G. K., Rundlöf, M. \& SMith, H. G. (2012): Organic farming improves pollination success in strawberries. - PloS One 7(2). https://doi.org/10.1371/journal. pone.0031599 
Ashman, T. L., Knight, T. M., Steets, J. A., Amarasekare, P., Burd, M., Campbell, D. R., Dudash, M. R., Johnston, M. O., Mazer, S. J., Mitchell, R. J., Morgan, M. T. \& Wilson, W. G. (2004): Pollen limitation of plant reproduction: ecological and evolutionary causes and consequences. - Ecology 85(9): 2408-2421. https://doi.org/10.1890/03-8024

BABAI, D. \& MolnÁr, Z. (2014): Small-scale traditional management of highly species-rich grasslands in the Carpathians. - Agriculture, Ecosystems \& Environment 182: 123-130. https://doi.org/10.1016/j.agee.2013.08.018

BABAI, D. \& Molnár, Z. (2016): Species-rich mountain grasslands through the eyes of the farmer: Flora, species composition, and extensive grassland management. - Martor 21: 146-149.

Babai, D., Tóth, A., Szentirmai, I., Biró, M., Máté, A., Demeter, L., Szépligeti, M., Varga, A., Molnár, Á., Kun, R. \& Molnár, Z. (2015): Do conservation and agri-environmental regulations effectively support traditional small-scale farming in East-Central European cultural landscapes? - Biodiversity and Conservation 24(13): 3305-3327. https:// doi.org/10.1007/s10531-015-0971-z

Ban-Calefariu, C. \& Sárospataki, M. (2007): Contributions to the knowledge of Bombus and Psithyrus genera (Apoidea: Apidae) in Romania. - Travaux du Muséum National d'Histoire Naturelle "Grigore Antipa" 1: 239-258.

BAN, C. M. (2005): Contributions to the knowledge of apoid hymenopterans (Hymenoptera: Megachilidae, Anthophoridae, Apidae) from Maramures (Romania). Part I. Travaux du Muséum National d'Histoire Naturelle "Grigore Antipa" 48: 289-301.

BAN, C. M. \&Tomozei, B. (2006): New data on the Apoid hymenopterans (Hymenoptera: Andrenidae, Anthophoridae, Apidae) from Dobrogea (Romania). - Travaux du Muséum National d'Histoire Naturelle "Grigore Antipa" 49: 307-318.

Batáry, P., Dicks, L. V., Kleijn, D. \& Sutherland, W. J. (2015): The role of agri-environment schemes in conservation and environmental management. - Conservation Biology 29(4): 1006-1016. https://doi.org/10.1111/cobi.12536

Baude, M., Kunin, W. E., Boatman, N. D., Conyers, S., Davies, N., Gillespie, M. A., Morton, R. D, Smart, S. M. \& Mемmotт, J. (2016): Historical nectar assessment reveals the fall and rise of floral resources in Britain. - Nature 530(7588): 85-88. https://doi. org/10.1038/nature16532

BAwA, K. S. (1990): Plant-pollinator interactions in tropical rain forests. - Annual Review of Ecology and Systematics 21: 399-422. https://doi.org/10.1146/annurev.es.21.110190.002151

Biesmeijer, J. C., Roberts, S. P., Reemer, M., Ohlemüller, R., Edwards, M., Peeters, T., Schaffers, A. P., Potts, S. G., Kleukers, R., Thomas, C. D, Settele, J. \& Kunin, W. E. (2006): Parallel declines in pollinators and insect-pollinated plants in Britain and the Netherlands. - Science 313(5785): 351-354. https://doi.org/10.1126/science.1127863

Brittain, C., Williams, N., Kremen, C. \& Klein, A. M. (2013): Synergistic effects of nonApis bees and honey bees for pollination services. - Proceedings of the Royal Society B: Biological Sciences 280(1754): 20122767. https://doi.org/10.1098/rspb.2012.2767

Dahlström, A., Iuga, A. M. \& Lennartsson, T. (2013): Managing biodiversity rich hay meadows in the EU: a comparison of Swedish and Romanian grasslands. - Environmental Conservation 40(2): 194-205. https://doi.org/10.1017/S0376892912000458

Darvill, B., O’Connor, S., Lye, G. C., Waters, J., Lepais, O. \& Goulson, D. (2010): Cryptic differences in dispersal lead to differential sensitivity to habitat fragmentation in two bumblebee species. - Molecular Ecology 19(1): 53-63. https://doi.org/10.1111/j.1365294X.2009.04423.x

De Heer, M., Kapos, V. \& Ten Brink, B. J. E. (2005): Biodiversity trends in Europe: development and testing of a species trend indicator for evaluating progress towards 
the 2010 target. - Philosophical Transactions of the Royal Society B: Biological Sciences 360(1454): 297-308. https://doi.org/10.1098/rstb.2004.1587

Doré, M., Fontaine, C. \& Thébault, E. (2021): Relative effects of anthropogenic pressures, climate, and sampling design on the structure of pollination networks at the global scale. - Global Change Biology 27(6): 1266-1280. https://doi.org/10.1111/gcb.15474

Dorresteijn, I., Loos, J., Hanspach, J. \& Fischer, J. (2015): Socioecological drivers facilitating biodiversity conservation in traditional farming landscapes. - Ecosystem Health and Sustainability 1(9): 1-9. https://doi.org/10.1890/EHS15-0021.1

Eeraerts, M., Vanderhaegen, R., Smagghe, G. \& Meeus, I. (2020): Pollination efficiency and foraging behaviour of honey bees and non-Apis bees to sweet cherry. - Agricultural and Forest Entomology 22(1): 75-82. https://doi.org/10.1111/afe.12363

Ellis, A. M., Myers, S. S. \& RicketTS, T. H. (2015): Do pollinators contribute to nutritional health? - PLoS One 10(1). https://doi.org/10.1371/journal.pone.0114805

Evans, D. (2006): The habitats of the European Union Habitats Directive. - Biology and Environment: Proceedings of the Royal Irish Academy 106: 167-173. https://doi.org/10.3318/ BIOE.2006.106.3.167

Gallai, N., Salles, J. M., Settele, J. \& Vaissière, B. E. (2009): Economic valuation of the vulnerability of world agriculture confronted with pollinator decline. - Ecological Economics 68(3): 810-821. https://doi.org/10.1016/j.ecolecon.2008.06.014

GATHMANN, A. \& TsChARNTKE, T. (2002): Foraging ranges of solitary bees. - Journal of Animal Ecology 71(5): 757-764. https://doi.org/10.1046/j.1365-2656.2002.00641.x

Goulson, D. (2003): Bumblebees: their behaviour and ecology. - Oxford University Press, USA.

Goulson, D., Hanley, M. E., Darvill, B., Ellis, J. S. \& Knight, M. E. (2005): Causes of rarity in bumblebees. - Biological Conservation 122(1): 1-8. https://doi.org/10.1016/j. biocon.2004.06.017

Goulson, D., Lye, G. C. \& Darvill, B. (2008): Decline and conservation of bumble bees. - Annual Review of Entomology 53: 191-208. https://doi.org/10.1146/annurev.ento.53.103106.093454

Havas, E., SÁrospataki, M. \& Józan, Zs. (2008): Új adatok a Tihanyi-félsziget vadméhfaunájával kapcsolatban. [New data on Apoid fauna of Tihany Peninsula.] - Állattani Közlemények 93: 17-24. [in Hungarian]

Hill, M. O. (1973): Diversity and evenness: a unifying notation and its consequences. Ecology 54(2): 427-432. https://doi.org/10.2307/1934352

Hoenn, P., Tscharntke, T., Tylianakis, J. M. \& Steffan-Dewenter, I. (2008): Functional group diversity of bee pollinators increases crop yield. - Proceedings of the Royal Society B: Biological Sciences 275(1648): 2283-2291. https://doi.org/10.1098/rspb.2008.0405

Ноoke, R. L., Martín-Duque, J. F. \& Pedraza, J. (2012): Land transformation by humans: a review. - GSA Today 22(12): 4-10. https://doi.org/10.1130/GSAT151A.1

Huband, S., McCracken, D. I. \& Mertens, A. (2010): Long and short-distance transhumant pastoralism in Romania: past and present drivers of change. - Practical Action Publishing. https://doi.org/doi:10.3362/2041-7136.2010.004

Klein, A. M., Vaissiere, B. E., Cane, J. H., Steffan-Dewenter, I., Cunningham, S. A., KreMEN, C. \& TsChARNTKE, T. (2007): Importance of pollinators in changing landscapes for world crops. - Proceedings of the Royal Society, B 274(1608): 303-313. https://doi. org/10.1098/rspb.2006.3721

Kovács-Hostyánszki, A., Földesi, R., Mózes, E., Szirák, Á., Fischer, J., Hanspach, J. \& BÁLDI, A. (2016): Conservation of pollinators in traditional agricultural landscapesnew challenges in Transylvania (Romania) posed by EU accession and recommendations for future research. - PloS One 11(6): e0151650. https://doi.org/10.1371/journal. pone. 0151650 
Kremen, C., Williams, N. M., Aizen, M. A., Gemmill-Herren, B., LeBuhn, G., Minckley, R., Packer, L., Potts, S. G., Roulston, T., Steffan-Dewenter, I., Vázquez, D. P., Winfree, R., Adams, L., Crone, E. E., Greenleaf, S. S., Keitt, T. H., Klein, A-M., Regetz, J., Ricketтs, T. H. (2007): Pollination and other ecosystem services produced by mobile organisms: a conceptual framework for the effects of land-use change. - Ecology Letters 10(4): 299-314. https://doi.org/10.1111/j.1461-0248.2007.01018.x

Kremen, C., Williams, N. M. \& Thorp, R. W. (2002): Crop pollination from native bees at risk from agricultural intensification. - Proceedings of the National Academy of Sciences 99(26): 16812-16816. https://doi.org/10.1073/pnas.262413599

Kun, R., Bartha, S., Malatinszky, Á., Molnár, Z., Lengyel, A. \& Babai, D. (2019): “Everyone does it a bit differently!": Evidence for a positive relationship between microscale land-use diversity and plant diversity in hay meadows. - Agriculture, Ecosystems \& Environment 283: 106556. https://doi.org/10.1016/j.agee.2019.05.015

MacInnis, G. \& Forrest, J. R. (2020): Field design can affect cross-pollination and crop yield in strawberry (Fragaria $\times$ ananassa D.). - Agriculture, Ecosystems E Environment 289: 106738. https://doi.org/10.1016/j.agee.2019.106738

Marini, L., Fontana, P., KlimeK, S., Battisti, A. \& Gaston, K. J. (2009): Impact of farm size and topography on plant and insect diversity of managed grasslands in the Alps. - Biological Conservation 142(2): 394-403. https://doi.org/10.1016/j.biocon.2008.10.034

Matache, I. \& Ban, C. M. (2006): Family Megachilidae (Hymenoptera: Apoidea) in Dobrogea (Romania). - Travaux du Muséum National d'Histoire Naturelle "Grigore Antipa" 49: 297-306.

Michener, C. D. (2000): The bees of the world. Vol. 1. - Johns Hopkins University Press, Baltimore.

Myklestad, Å. \& SÆtersdal, M. (2003): Effects of reforestation and intensified land use on vascular plant species richness in traditionally managed hay meadows. - Annales Botanici Fennici 40(6): 423-441.

Newbold, T., Hudson, L. N., Hill, S. L., Contu, S., Lysenko, I., Senior, R. A., Börger, L., Bennett, D.J., Choimes, A., Collen, B. \& Day, J. (2015): Global effects of land use on local terrestrial biodiversity. - Nature 520(7545): 45-50. https://doi.org/10.1038/ nature14324

Nieto, A., Roberts, S. P. M., Kemp, J., Rasmont, P., Kuhlmann, M., García Criado, M., Biesmeijer, J. C., Bogusch, P., Dathe, H. H., De la Rúa, P., De Meulemeester, T., Dehon, M., Dewulf, A., Ortiz-Sánchez, F. J., Lhomme, P., Pauly, A., Potts, S. G., Praz, C., Quaranta, M., Radchenko, V. G., Scheuchl, E., Smit, J., Straka, J., Terzo, M., Tomozir, B., Window, J. \& Michez, D. (2014): European Red List of bees. - Publication Office of the European Union, Luxembourg.

Poschlod, P., Bakker, J. P. \& Kahmen, S. (2005): Changing land use and its impact on biodiversity. - Basic and Applied Ecology 6(2): 93-98. https://doi.org/10.1016/j.baae.2004.12.001

Potts, S. G., Biesmeijer, J. C., Kremen, C., Neumann, P., Schweiger, O. \& Kunin, W. E. (2010): Global pollinator declines: trends, impacts and drivers. - Trends in Ecology and Evolution 25(6): 345-353. https://doi.org/10.1016/j.tree.2010.01.007

Potts, S. G., Imperatriz-Fonseca, V., Ngo, H. T., Aizen, M. A., Biesmeijer, J. C., Breeze, T. D., Dicks, L. V., Garibaldi, L. A., Hill, R., Settele, J. \& Vanbergen, A. J. (2016): Safeguarding pollinators and their values to human well-being. - Nature 540(7632): 220-229. https://doi.org/10.1038/nature20588

Potts, S. G., Vulliamy, B., Roberts, S., O’Toole, C., Dafni, A., Ne'eman, G. \& Willmer, P. (2005): Role of nesting resources in organising diverse bee communities in a Mediter- 
ranean landscape. - Ecological Entomology 30(1): 78-85. https://doi.org/10.1111/j.03076946.2005.00662.x

Quintero, C., Morales, C. L. \& Aizen, M. A. (2010): Effects of anthropogenic habitat disturbance on local pollinator diversity and species turnover across a precipitation gradient. - Biodiversity and Conservation 19(1): 257-274. https://doi.org/10.1007/s10531009-9720-5

Samu, F., Neidert, D., Szita, É., Fetykó, K., Botta-Dukát, Z. \& Horváth, A. (2010): The role of 'low-input' agri-environmental schemes in the enhancement of functional biodiversity of Hungarian arable fields. - IOBC/WPRS Bulletin 56: 105-108.

Sárospataki, M. G., Bakos, R., Horváth, A., Neidert, D. \& Horváth, V. (2016): The role of local and landscape level factors in determining bumblebee abundance and richness. - Acta Zoologica Academiae Scientiarum Hungaricae 62(4): 387-407. https://doi. org/10.17109/AZH.62.4.387.2016

SÁrospataki, M., BÁldi, A., Batáry, P., Józan, Z., Erdôs, S. \& Rédei, T. (2009): Factors affecting the structure of bee assemblages in extensively and intensively grazed grasslands in Hungary. - Community Ecology 10(2): 182-188. https://doi.org/10.1556/ComEc.10.2009.2.7

SÁrospataki, M. \& Fazekas, J. P. (1995): Ecological characteristics of bee communities on a sandy grassland. - Tiscia 29: 41-46.

Senapathi, D., Carvalheiro, L. G., Biesmeijer, J. C., Dodson, C. A., Evans, R. L., McKerchar, M., Morton R. D., Moss, E. D., Roberts S. P. M., Kunin, W. E \& Potts, S. G. (2015): The impact of over 80 years of land cover changes on bee and wasp pollinator communities in England. - Proceedings of the Royal Society B: Biological Sciences 282(1806): 20150294. https://doi.org/10.1098/rspb.2015.0294

Tilman, D., Fargione, J., Wolff, B., D’Antonio, C., Dobson, A., Howarth, R., Schindler, D., Schlesinger, W. H., Simberloff, D. \& Swackhamer, D. (2001): Forecasting agriculturally driven global environmental change. - Science 292(5515): 281-284. https:// doi.org/10.1126/science.1057544

Tomoziı, B. \& Toma, V. C. (2011): New records of megachilid bees (Hymenoptera: Apiformes: Megachilidae) from Romania. - Studii şi Comunicări, Complexul Muzeal de Stiintele Naturii "Ion Borcea" Вacău 24: 61-68.

Tomozir, B. (2020): Bees of Romania. http://www.beesofromania.ro [accessed: 11/07/2020]

Veen, P., Jefferson, R., De Smidt, J. \& van der StraAten, J. (2009): Grasslands in Europe of high nature value. - KNNV Publishing, Zeist, 320 pp. https://doi.org/10.1163/9789004278103

Winfree, R., Aguilar, R., Vázquez, D. P., LeBuhn, G. \& Aizen, M. A. (2009): A meta-analysis of bees' responses to anthropogenic disturbance. - Ecology 90(8): 2068-2076. https://doi.org/10.1890/08-1245.1

Winfree, R., Bartomeus, I. \& Cariveau, D. P. (2011): Native pollinators in anthropogenic habitats. - Annual Review of Ecology, Evolution, and Systematics 42: 1-22. https://doi. org/10.1146/annurev-ecolsys-102710-145042

Woodcock, B. A., Edwards, M., Redhead, J., Meek, W. R., Nuttall, P., Falk, S., NowakowsKI, M. \& Pywell, R. F. (2013): Crop flower visitation by honeybees, bumblebees and solitary bees: Behavioural differences and diversity responses to landscape. - Agriculture, Ecosystems \& Environment 171: 1-8. https://doi.org/10.1016/j.agee.2013.03.005 http1: TomoziI, B.: Bees of Romania. http://www.beesofromania.ro [accessed: 11/07/2020] http2: Elveszett Világ Természetvédelmi-, Turista és Barlangász Egyesület, Barót. http://www. vargyasszoros.org/ [accessed: 11/07/2020]

Received July 14, 2020, accepted January 6, 2021, published May 31, 2021 


\section{APPENDIX}

The number of individuals, dominance and IUCN status of collected species. EN (Endangered), NT (Near Threatened), DD (Data Deficient), LC (Least Concern) species

\begin{tabular}{|c|c|c|c|c|c|c|}
\hline Species & Filia & Merești & Vârghiș & Sum & Dominance & IUCN \\
\hline Andrena bicolor & & 6 & & 6 & 0.32 & $\mathrm{LC}$ \\
\hline Andrena combinata & & & 2 & 2 & 0.11 & DD \\
\hline Andrena dorsata & 4 & 5 & & 9 & 0.48 & DD \\
\hline Andrena flavipes & 56 & 12 & 25 & 93 & 4.94 & LC \\
\hline Andrena fulvicornis & 4 & & & 4 & 0.21 & DD \\
\hline Andrena hattorfiana & 3 & 6 & 5 & 14 & 0.74 & NT \\
\hline Andrena labialis & 2 & 1 & 3 & 6 & 0.32 & DD \\
\hline Andrena labiata & 1 & 2 & 1 & 4 & 0.21 & DD \\
\hline Andrena minutula & & 4 & & 4 & 0.21 & DD \\
\hline Andrena minutuloides & 5 & 1 & & 6 & 0.32 & DD \\
\hline Andrena nitida & 1 & 1 & 1 & 3 & 0.16 & $\mathrm{LC}$ \\
\hline Andrena nitidiuscula & 2 & & 1 & 3 & 0.16 & $\mathrm{LC}$ \\
\hline Andrena ovatula & 22 & 21 & 22 & 65 & 3.45 & NT \\
\hline Andrena pandellei & 1 & 3 & 3 & 7 & 0.37 & $\mathrm{LC}$ \\
\hline Andrena proxima & & 1 & & 1 & 0.05 & DD \\
\hline Andrena schencki & 6 & 2 & 3 & 11 & 0.59 & DD \\
\hline Andrena strohmella & & & 1 & 1 & 0.05 & $\mathrm{LC}$ \\
\hline Andrena subopaca & & & 1 & 1 & 0.05 & $\mathrm{LC}$ \\
\hline Andrena susterai & 1 & & & 1 & 0.05 & DD \\
\hline Andrena taraxaci & 4 & & 2 & 6 & 0.32 & DD \\
\hline Andrena ungeri & 1 & & & 1 & 0.05 & $\mathrm{LC}$ \\
\hline Anthidium manicatum & & & 2 & 2 & 0.11 & $\mathrm{LC}$ \\
\hline Anthophora aestivalis & 2 & 2 & 1 & 5 & 0.27 & $\mathrm{LC}$ \\
\hline Anthophora furcata & 1 & 1 & & 2 & 0.11 & $\mathrm{LC}$ \\
\hline Bombus argillaceus & & 4 & 4 & 8 & 0.43 & $\mathrm{LC}$ \\
\hline Bombus campestris & & 2 & 1 & 3 & 0.16 & $\mathrm{LC}$ \\
\hline Bombus hortorum & 3 & 12 & 43 & 58 & 3.08 & $\mathrm{LC}$ \\
\hline Bombus humilis & 15 & 49 & 75 & 139 & 7.39 & $\mathrm{LC}$ \\
\hline Bombus hypnorum & & 3 & 1 & 4 & 0.21 & $\mathrm{LC}$ \\
\hline Bombus lapidarius & & 2 & 7 & 9 & 0.48 & $\mathrm{LC}$ \\
\hline Bombus pascuorum & 9 & 23 & 41 & 73 & 3.88 & $\mathrm{LC}$ \\
\hline Bombus pratorum & & & 1 & 1 & 0.05 & $\mathrm{LC}$ \\
\hline
\end{tabular}




\begin{tabular}{|c|c|c|c|c|c|c|}
\hline Species & Filia & Merești & Vârghiș & Sum & Dominance & IUCN \\
\hline Bombus ruderarius & 3 & 3 & 12 & 18 & 0.96 & $\mathrm{LC}$ \\
\hline Bombus subterraneus & & 3 & & 3 & 0.16 & $\mathrm{LC}$ \\
\hline Bombus sylvarum & 2 & 4 & 16 & 22 & 1.17 & $\mathrm{LC}$ \\
\hline Bombus terrestris & 108 & 274 & 329 & 711 & 37.8 & LC \\
\hline Camptopoeum friesei & & 1 & & 1 & 0.05 & LC \\
\hline Ceratina cyanea & 1 & & & 1 & 0.05 & LC \\
\hline Chelostoma campanularum & & 1 & & 1 & 0.05 & $\mathrm{LC}$ \\
\hline Chelostoma florisomne & 1 & & 5 & 6 & 0.32 & LC \\
\hline Coelioxys conoidea & & & 1 & 1 & 0.05 & LC \\
\hline Colletes similis & 2 & & 1 & 3 & 0.16 & $\mathrm{LC}$ \\
\hline Dasypoda hirtipes & & 1 & & 1 & 0.05 & $\mathrm{LC}$ \\
\hline Epeoloides coecutiens & & & 1 & 1 & 0.05 & $\mathrm{LC}$ \\
\hline Eucera interrupta & 1 & & & 1 & 0.05 & LC \\
\hline Eucera longicornis & 4 & 16 & 15 & 35 & 1.86 & $\mathrm{LC}$ \\
\hline Eucera nigrescens & 14 & 7 & 3 & 24 & 1.28 & $\mathrm{LC}$ \\
\hline Eucera proxima & & 1 & & 1 & 0.05 & DD \\
\hline Eucera taurica & & 1 & 1 & 2 & 0.11 & DD \\
\hline Halictus eurygnathus & 6 & 3 & 10 & 19 & 1.01 & $\mathrm{LC}$ \\
\hline Halictus fulvipes & 1 & & & 1 & 0.05 & $\mathrm{LC}$ \\
\hline Halictus langobardicus & 12 & 15 & 10 & 37 & 1.97 & LC \\
\hline Halictus maculatus & 7 & 2 & 5 & 14 & 0.74 & $\mathrm{LC}$ \\
\hline Halictus quadricinctus & & 1 & & 1 & 0.05 & NT \\
\hline Halictus rubicundus & 4 & 3 & 6 & 13 & 0.69 & LC \\
\hline Halictus scabiosae & 2 & & & 2 & 0.11 & $\mathrm{LC}$ \\
\hline Halictus seladonius & 2 & 1 & 1 & 4 & 0.21 & $\mathrm{LC}$ \\
\hline Halictus sexcinctus & 1 & 2 & & 3 & 0.16 & $\mathrm{LC}$ \\
\hline Halictus smaragdulus & & & 1 & 1 & 0.05 & LC \\
\hline Halictus subauratus & 8 & 3 & 2 & 13 & 0.69 & $\mathrm{LC}$ \\
\hline Halictus tumulorum & 13 & 8 & 12 & 33 & 1.75 & $\mathrm{LC}$ \\
\hline Hoplitis leucomelana & & & 1 & 1 & 0.05 & LC \\
\hline Hoplitis tridentata & & & 1 & 1 & 0.05 & $\mathrm{LC}$ \\
\hline Hylaeus annularis & 2 & & & 2 & 0.11 & DD \\
\hline Hylaeus brevicornis & 2 & 1 & & 3 & 0.16 & $\mathrm{LC}$ \\
\hline Hylaeus communis & & 1 & 1 & 2 & 0.11 & $\mathrm{LC}$ \\
\hline
\end{tabular}




\begin{tabular}{|c|c|c|c|c|c|c|}
\hline Species & Filia & Merești & Vârghiș & Sum & Dominance & IUCN \\
\hline Hylaeus confusus & 2 & 2 & 1 & 5 & 0.27 & LC \\
\hline Hylaeus cornutus & 1 & & & 1 & 0.05 & $\mathrm{LC}$ \\
\hline Hylaeus duckei & 1 & & & 1 & 0.05 & DD \\
\hline Hylaeus variegatus & 2 & & & 2 & 0.11 & $\mathrm{LC}$ \\
\hline Lasioglossum albipes & 3 & 3 & 1 & 7 & 0.37 & $\mathrm{LC}$ \\
\hline Lasioglossum calceatum & 11 & 36 & 12 & 59 & 3.14 & $\mathrm{LC}$ \\
\hline Lasioglossum convexiusculum & & & 1 & 1 & 0.05 & NT \\
\hline Lasioglossum corvinum & 3 & 5 & & 8 & 0.43 & $\mathrm{LC}$ \\
\hline Lasioglossum costulatum & & 1 & & 1 & 0.05 & NT \\
\hline Lasioglossum discum & 4 & 8 & 1 & 13 & 0.69 & $\mathrm{LC}$ \\
\hline Lasioglossum fulvicorne & & & 1 & 1 & 0.05 & $\mathrm{LC}$ \\
\hline Lasioglossum glabriusculum & 2 & 2 & 3 & 7 & 0.37 & $\mathrm{LC}$ \\
\hline Lasioglossum interruptum & 1 & & & 1 & 0.05 & $\mathrm{LC}$ \\
\hline Lasioglossum laevigatum & & 1 & 1 & 2 & 0.11 & NT \\
\hline Lasioglossum laticeps & 2 & 1 & 3 & 6 & 0.32 & $\mathrm{LC}$ \\
\hline Lasioglossum lativentre & 16 & 10 & 7 & 33 & 1.75 & $\mathrm{LC}$ \\
\hline Lasioglossum leucozonium & 2 & 1 & 4 & 7 & 0.37 & $\mathrm{LC}$ \\
\hline Lasioglossum lineare & & & 1 & 1 & 0.05 & DD \\
\hline Lasioglossum majus & & 1 & 2 & 3 & 0.16 & NT \\
\hline Lasioglossum minutulum & & & 1 & 1 & 0.05 & NT \\
\hline Lasioglossum morio & & 2 & 3 & 5 & 0.27 & $\mathrm{LC}$ \\
\hline Lasioglossum nitidiusculum & 3 & & & 3 & 0.16 & $\mathrm{LC}$ \\
\hline Lasioglossum parvulum & & & 1 & 1 & 0.05 & $\mathrm{LC}$ \\
\hline Lasioglossum pauxillum & 9 & 11 & 5 & 25 & 1.33 & $\mathrm{LC}$ \\
\hline Lasioglossum politum & 10 & 2 & 1 & 13 & 0.69 & $\mathrm{LC}$ \\
\hline Lasioglossum puncticolle & 1 & 6 & & 7 & 0.37 & $\mathrm{LC}$ \\
\hline Lasioglossum villosulum & 3 & 7 & & 10 & 0.53 & $\mathrm{LC}$ \\
\hline Lasioglossum zonulum & 4 & 2 & & 6 & 0.32 & $\mathrm{LC}$ \\
\hline Megachile centuncularis & & & 1 & 1 & 0.05 & $\mathrm{LC}$ \\
\hline Megachile ericetorum & & 1 & & 1 & 0.05 & $\mathrm{LC}$ \\
\hline Megachile flabellipes & & & 5 & 5 & 0.27 & DD \\
\hline Megachile lagopoda & & & 1 & 1 & 0.05 & $\mathrm{LC}$ \\
\hline Megachile maritima & & & 2 & 2 & 0.11 & DD \\
\hline Megachile melanopyga & & & 1 & 1 & 0.05 & $\mathrm{LC}$ \\
\hline Megachile octosignata & & & 1 & 1 & 0.05 & DD \\
\hline
\end{tabular}




\begin{tabular}{|c|c|c|c|c|c|c|}
\hline Species & Filia & Merești & Vârghiș & Sum & Dominance & IUCN \\
\hline Megachile pilicrus & 1 & & 4 & 5 & 0.27 & $\mathrm{DD}$ \\
\hline Megachile pilidens & & & 3 & 3 & 0.16 & LC \\
\hline Megachile pyrenaea & 1 & & 1 & 2 & 0.11 & DD \\
\hline Megachile versicolor & 1 & & 1 & 2 & 0.11 & DD \\
\hline Megachile willughbiella & 5 & 2 & 3 & 10 & 0.53 & LC \\
\hline Melitta haemorrhoidalis & & 2 & & 2 & 0.11 & LC \\
\hline Melitta leporina & 2 & 2 & 3 & 7 & 0.37 & LC \\
\hline Melitta nigricans & 1 & & & 1 & 0.05 & LC \\
\hline Nomada armata & & 3 & 1 & 4 & 0.21 & NT \\
\hline Nomada bluethgeni & 1 & & & 1 & 0.05 & $\mathrm{LC}$ \\
\hline Nomada femoralis & & & 1 & 1 & 0.05 & LC \\
\hline Nomada marshamella & 1 & & & 1 & 0.05 & LC \\
\hline Nomada rhenana & 1 & & & 1 & 0.05 & NT \\
\hline Osmia aurulenta & 1 & & 1 & 2 & 0.11 & $\mathrm{LC}$ \\
\hline Osmia caerulescens & & 1 & & 1 & 0.05 & $\mathrm{LC}$ \\
\hline Osmia leaiana & & & 1 & 1 & 0.05 & LC \\
\hline Pseudoanthidium nanum & 1 & & & 1 & 0.05 & $\mathrm{LC}$ \\
\hline Rophites quinquespinosus & 8 & 5 & 5 & 18 & 0.96 & NT \\
\hline Sphecodes ephippius & 1 & & & 1 & 0.05 & LC \\
\hline Sphecodes gibbus & 1 & & & 1 & 0.05 & $\mathrm{LC}$ \\
\hline Sphecodes puncticeps & 1 & & & 1 & 0.05 & $\mathrm{LC}$ \\
\hline Tetraloniella alticincta & 1 & & & 1 & 0.05 & $\mathrm{LC}$ \\
\hline Tetraloniella dentata & 3 & 1 & & 4 & 0.21 & LC \\
\hline Tetraloniella nana & 1 & & & 1 & 0.05 & DD \\
\hline Tetraloniella salicariae & 3 & 1 & & 4 & 0.21 & $\mathrm{DD}$ \\
\hline Trachusa byssina & & 2 & 11 & 13 & 0.69 & LC \\
\hline Trachusa interrupta & & & 1 & 1 & 0.05 & EN \\
\hline Xylocopa valga & & 2 & 14 & 16 & 0.85 & $\mathrm{LC}$ \\
\hline
\end{tabular}


